form is the ancestral one, just as the conclusion that Africa is the ancestral home of the species is justified by the predominant amount of mimicry of which $D$. chrysippus has been the attractive centre in this as compared with all other parts of its vast range. The time which would be necessary to bring about so deep an impression on so many diverse members of the surrounding insect fauna, justifies the view that the type form has persisted as it is for a very long period, and that it is an extremely ancient inhabitant of the country in which, far beyond all others, these effects are marked.

The statement on p. 6r, that the varieties of the female Hypolimnas misippus are nowhere found "where the inedible chrysippus and its varieties do not occur," is an error. For many years now-certainly between twenty and thirty-the former species has been established in some of the West Indian islands and certain parts of tropical South America.

There are several errors in the spelling of names of species, and the figures in the plates are often wrongly sexed and sometimes wrongly named in the descriptions.

The doubtful points in the paper have been here discussed at some length, and errors of detail pointed out ; but the present writer would wish in conclusion again to emphasise the interest of this short communication, and again to draw attention to the usefulness of the numerous illustrations.

E. B. P.

\section{THE UNITED STATES NATIONAL} MUSEUM. ${ }^{1}$

THE last report issued by the U.S. National Museum furnishes abundant evidence of the energy with which America is now conducting scientific inquiry, and of the zeal with which she is augmenting the rich and varied collections preserved at Washington. Like most collections of the same character, the National Museum owes its origin to the generosity and enterprise of private individuals; and it was only after some years of precarious existence that it obtained due assistance and recognition from the State. The society organised in I 840 , and called the "National Institute," may perhaps be regarded as the parent of the present Museun. Though prosperous - during the first few years of its existence, it failed to interest a wide body of the public, and it was reserved for the Smithsonian Institution to obtain official recognition as the only lawful place of deposit for the national scientific collections. In 1846 such recognition was accorded by Act of Congress, and from that year until the present time the work of collecting and exhibiting new material has been carried on without interruption.

One striking characteristic which distinguishes the National Museum from similar institutions in other countries is to be found in the somewhat restricted area to which it has confined its attentions. While the museums of Europe include exhibits from all regions of the globe, the United States collections are, with a few exceptions, exclusively North American. The advantage of so restricting the area of research is obvious, for by this means the Museum has been enabled to attain an unrivalled completeness in the departments of science to which its energies have been devoted. The authorities have also found considerable assistance in the fact that for nearly twenty years they have received all collections of minerals and objects bearing on natural history archæology and ethnology which have been made during the numerous surveys undertaken by the Government of the United States.

The present report occupies over eleven hundred pages,

1 Report of the United States National Museum under the direction of the Smithsonian Institution, for the year ending June 30,1896 . Pp. xxiv.

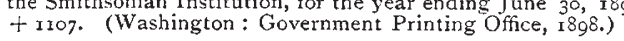

NO. I 549 , VOL. 60$]$ and it would be impossible in a short notice to do more than sketch the general nature of its contents, and to indicate the sections into which it naturally falls. The volume is divided into two unequal parts, of which the first consists of the report of the late Mr. Brown Goode, assistant secretary of the Smithsonian Institution, to which are attached a number of appendices. This report covers the whole ground of the Museun's activities, describing new accessions, the arrangement and labelling of the collections, the work of exploration conducted during the year, the official publications and contributions made to scientific literature, and the work done in connection with visitors and students at the Museum. These general summaries are followed by detailed reports of the work done in the various scientific: departments, concluding with the report of the administration department of the Museum. After a perusal of these reports it is evident that, in addition to prosecuting: scientific inquiry, the Museum is doing much to render its resources available to the public at large. By its system of exchange and its distribution of duplicate

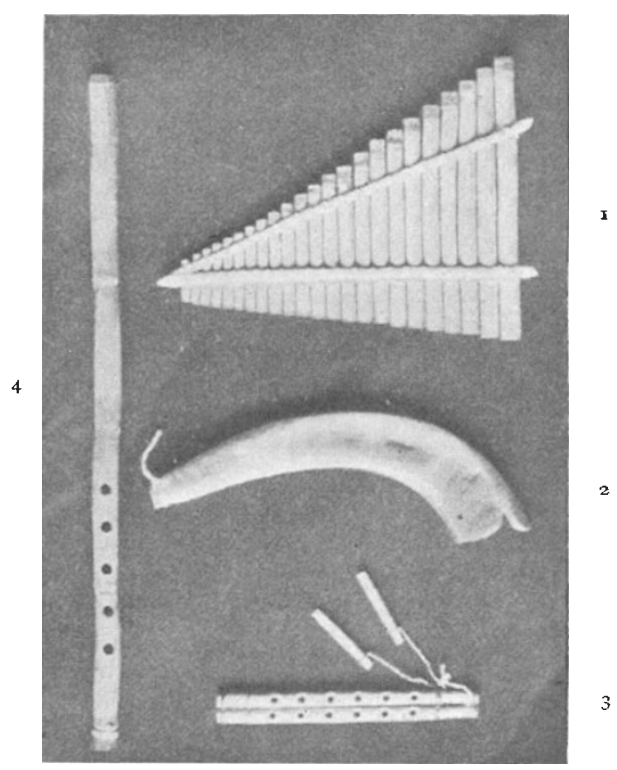

FIG. I.-Wind Musical Instruments. r, Reeds or Pan Pipes ; 2, Ram's Horn; 3, Double Flute; 4, Flute.

specimens, a large number of local museums in the United States have benefited in the course of the year.

The second and larger portion of the volume is of greater general interest, for it consists of a number of original papers describing and illustrating the collections preserved in the Museum. Of these, perhaps the most important is the paper on "Prehistoric Art" by Mr. Thomas Wilson, the curator of the Division of Prehistoric Archæology. Although in the main describing the specimens under his charge, Mr. Wilson has not confined himself to the art of primitive America, but has given a very exhaustive sketch of the products of early civilisations all over the world, and his essay forms a valuable contribution to the study of prehistoric man. Another interesting paper devoted to a special subject is contributed by Mr. Walter Hough, the assistant curator of the Division of Ethnology, who has written a monograph on "The Lamp of the Eskimo." The Museum possesses a very complete collection of Eskimo lamps, comprising examples used by nearly every tribe from Labrador to the Aleutian Islands. The lamps are 
classified according to their provenance, and full descriptions and illustrations are given of a large number of typical examples.

Two other papers in the volume deserve special mention, as they illustrate another side of the Museum's activities. In addition to their purely scientific work,

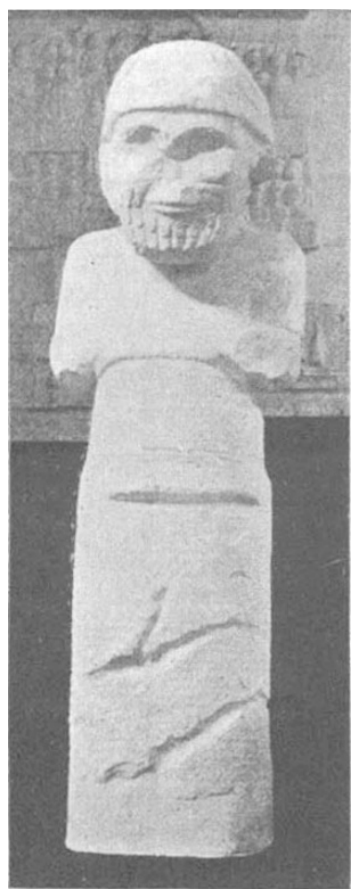

EIG. 2.-Colossal Statue of the God Hadad, Gertch in, Northern Syria,

special attention is now being given by its officers to the function of the Museum as an educational institution, and to the popularisation of the collections. At the International Exposition held at Atalanta in 1895. special collections were organised and arranged for the illustration of distinct subjects of study, and the de- from ancient as well as modern times throw valuable light on the text of the Old Testament narratives; one of the plates, for instance, which is here reproduced, is intended to illustrate some of the wind instruments mentioned in the Bible (Fig. I). Moreover, by means of a fine series of casts, reproduced by photography, the antiquities of Western Asia during the principal periods of Old Testament history are fully represented. Two good specimens of these are here given-a colossal statue of the god Hadad from Northern Syria (Fig. 2), and a bas-relief of a lion chase in the so-called "Hittite" style (Fig. 3), which exhibits many interesting points of resemblance to its Assyrian prototypes. The other paper deals with "Chess and Playing Cards," and consists of a catalogue of games and implements of divination, which were also exhibited at Atalanta. This collection was formed by the Museum in collaboration with the University of Pennsylvania, and it is here described by Mr. Stewart Culin, the director of the Museum of Archæology and Palæontology in that University. We have not done more than indicate the varied nature of the contents of this report, but sufficient has been said to show that the study of science and archæology in the United States is receiving valuable encouragement from the Government, and that the system and methods there adopted compare very favourably with those in many European museums.

AN IMPROVED LIQUID INTERRUPTER FOR INDUCTION COILS.

THE following is a description of an improved form of Wehnelt-Caldwell interrupter for induction coils, devised by the writer in conjunction with Mr. J. C. M. Stanton and Mr. H. Tyson Wolff.

The two electrodes of sheet lead $\mathrm{C}$ and $\mathrm{D}$ dip into dilute sulphuric acid, contained in the glass vessel A. The electrodes are separated by a hollow glass or porcelain cylinder $\mathrm{B}$, which surrounds the electrode $\mathrm{C}$. This cylinder is closed at the bottom with the exception of a circular aperture $\mathrm{E}$, about three or four millimetres in diameter. Through this aperture projects the small end of the conical glass or porcelain valve $F$, which by means of the screwed carrier tube $\mathrm{H}$ and the milled nut $\mathrm{G}$, can be raised or lowered so as to open or close the aperture to any desired extent. As when the apparatus is at work

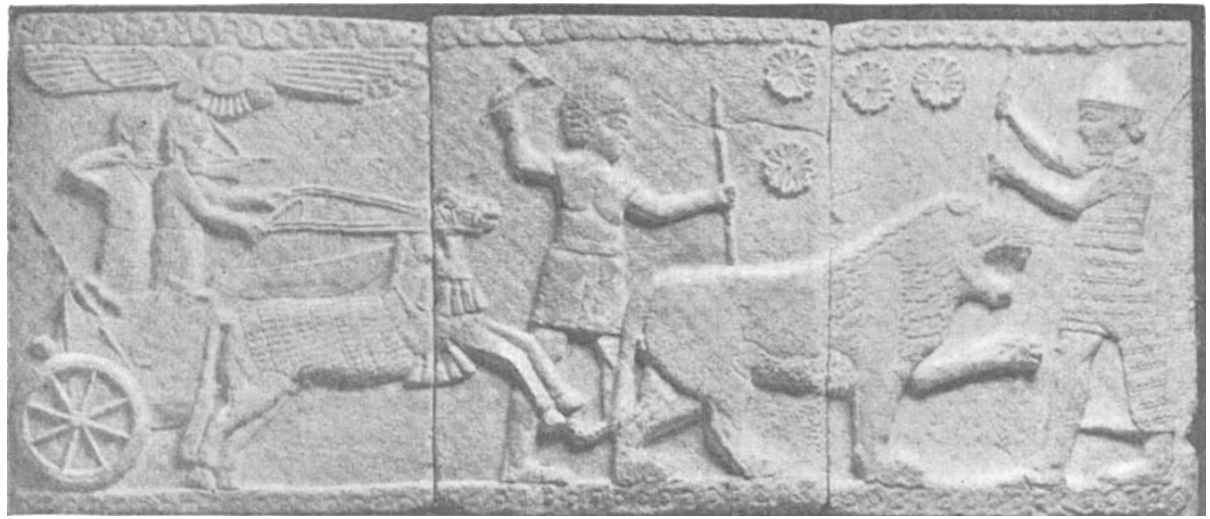

FrG. 3.-Hittite Lion Chase.

scriptions that were published at the time are here reprinted as a record of the collections that were shown. Of these papers, that on "Biblical Antiquities" is written by Dr. Cyrus Adler and Dr. Cassanowitz, who describe a number of exhibits illustrating the geology, flora and fauna of Palestine, while other exhibits dating the liquid is found to rise in the cylinder $B$, the latter is provided with an overflow at $\mathrm{J}$.

The interruptions take place in the valve aperture, and appear to be due to the formation of gas or steam therein. The extent to which the valve is open or shut determines the amount of current passed, and the NO. I 549 , VOL. 60 ] 